\title{
Kajian Karakter Kepemimpinan Oda Nobunaga Dalam Novel Shinsho Taikōki Karya Eiji Yoshikawa Dengan Pendekatan Teori Praktik Bourdieu
}

\author{
Silvi Mega Suri*, Haryono, Yudi Suryadi \\ Program Studi Sastra Jepang, Universitas Jenderal Soedirman, Purwokerto, Indonesia \\ email: coffeeeaddict789@gmail.com*
}

DOI: 10.20884/1.jlitera.2020.2.1.2617

\begin{abstract}
This research analyzes the character of Oda Nobunaga's leadership from his social side. The purpose of writing this essay is to describe habitations, arenas and capital, and the third correlation which deforms the leadership character of Oda Nobunaga. In writing this essay used a book study method. The technical analysis of the data used is a descriptive analysis. The conclusion of this study has been found that (1) the Shinsho Taikoki pictures the form of one's habitation in determining action. Natural changes in agents continue to move around as time goes on. The movement is a result of his experience, upbringing, and environment; (2) there are three arenas in the Shinsho Taikokki, which is the power arena, the economic arena and the intellectual arena. These three arenas stand out from two factors, among them because of the dominant class, and where that agent's capital was obtained; (3) the capital found in the agent of this novel has three, which are social, symbolic and cultural capital. (4) the leadership character of the three social concepts consists of seven characters: Flexibility, ability to determine scale of priorities, analytic capabilities, future orientation, firmness, and exemplary.

\section{Keywords:}

Shinsho Taikōki, Oda

Nobunaga, leadership, theory

of practice

Article Info:

First received:

20 April 2020

Available online:

30 November 2020
\end{abstract}

\section{PENDAHULUAN}

Menurut Fahdiah, sastra dapat dikatakan sebagai cerminan masyarakat, atau dianggap sebagai salinan kehidupan, yang tidak berarti seluruhnya tergambar dalam sastra, diantaranya adalah dari gambaran masalah masyarakat secara umum dari berbagai sudut pandang. Sastra menurut Esten (2013:3) adalah pengungkapan dari fakta artistik dan imajinatif sebagai manifestasi kehidupan manusia (dan masyarakat) melalui bahasa sebagai medium dan memiliki efek yang positif terhadap kehidupan manusia.

Seringkali diketahui bahwa orang-orang tidak begitu tertarik dengan apa yang terjadi sebelum dunia yang ditinggali mereka ini, tetapi para penulis memiliki caranya sendiri untuk dapat membangkitkan para pembaca atau penikmat karya sastra menjadi tertarik dengan sesuatu yang berbau sejarah seperti contohnya sebuah karya yang disajikan dalam bentuk cerpen atau novel.

Karya sastra yang memiliki tema dan nilai sejarah sudah banyak dijumpai di era saat ini. Sebab, dalam suatu karya dapat menceritakan kembali kisah di zaman sebelumnya walaupun bukan dalam bentuk visualisasi melainkan ke dalam bentuk bacaan yang lebih menarik dan diminati setiap kalangan, bisa dalam bentuk buku bergambar atau karya fiksi berupa cerpen atau novel. Salah satu novel epik yang populer dari Jepang berjudul Shinsho Taikōki karya Eiji Yoshikawa.

Novel ini menceritakan tentang pergolakan menjelang dekade abad keenam belas. Kekaisaran Jepang mengalami kacau balau di kalangan ke-shogun-an berhamburan dan para panglima musuh berusaha merebut kemenangan. Ditengah-tengah penghancuran ini, muncul tiga orang yang bercita-cita mempersatukan bangsa; Nobunaga Oda, Ieyasu Tokugawa dan Hideyoshi Toyotomi. 
Dalam penelitian ini peneliti menggunakan teori dari Pierre Bourdieu. Pemikiran Bourdieu sangat berpengaruh dalam bidang ilmu sosial, terlebih dalam kajian budaya. Teori yang dikemukakan oleh Bourdieu dikenal dengan istilah teori praktik. Pada teori ini Bourdieu mengkombinasikan ketiga konsep (habitus, arena, dan modal) yang berpusat pada struktur pembentukan kehidupan sosial.

Peran dan karakter setiap tokoh yang membangun cerita tersebut pun berbeda-beda. Misalnya, tokoh Oda Nobunaga sebagai pemimpin marga dan majikan Hideyoshi dengan karakter yang dikatakan dalam novel tersebut bagai setan berwujud manusia, sehingga banyak pembaca yang mengambil kesimpulan dengan Nobunaga adalah orang yang jahat. Namun, peneliti ingin memberikan pandangan lain terhadap Nobunaga dari sisi sosialnya sebagai seorang pemimpin.

\section{TINJAUAN PUSTAKA}

\section{Sosiologi Sastra}

Menurut Swingewood (dalam Faruk, 2016:1), sosiologi sastra sebagai studi ilmiah dan objektif mengenai manusia dalam masyarakat, studi mengenai lembaga dan proses-proses sosial.

\section{Teori Sosiologi Sastra Bourdieu}

Kuswandoro (2016) menjelaskan, bahwa teori yang dikembangkan Bourdieu berorientasi pada hubungan dialektik antara struktur objektif dan fenomena subjektif dalam melihat realitas sosial yang disebut strukturalisme konstruktif (constructivist structuralism), atau Bourdieu menyebutnya dengan istilah strukturalisme genetis.

\section{HABITUS}

Bourdieu (dalam Santoso, 2012:xv) pun menyatakan secara formal mendefinisikan habitus sebagai sistem disposisi yang bertahan lama dan bisa dialihpindahkan (transposabale), struktur yang disrukturkan yang diasumsikan berfungsi sebagai penstruktur struktur-struktur (structured structures predisposed to function as structuring structures), yaitu sebagai prinsipprinsip yang melahirkan dan mengorganisasikan praktik-praktik dan representasi-representasi yang bisa diadaptasikan secara objektif kepada hasil-hasilnya tanpa mengandaikan suatu upaya sadar mencapai tujuan-tujuan tertentu atau penguasaan cepat atas cara dan operasi yang diperlukan untuk mencapainya.

\section{ARENA}

Bourdieu melihat arena, menurut definisinya, sebagai arena pertempuran, dimana struktur arena menopang dan mengarahkan strategi yang digunakan oleh orang-orang yang menduduki posisi ini untuk berupaya mengamankan atau meningkatkan posisi mereka, dan menerapkan prinsip hierarkisasi yang paling cocok untuk produk mereka. Menurut Wattimena (2012:3), konsep arena ikut mendukung habitus seseorang. Artinya, arena dan habitus sangat terikat erat. Untuk bisa berhasil dalam salah satu arena hidup, orang perlu mempunyai habitus yang tepat untuk arena itu. Jika ia tidak memiliki habitus yang tepat untuk satu arena, maka ia, kemungkinan besar, akan gagal dalam arena yang telah ia pilih tersebut.

\section{KAPITAL}

Kapital atau modal menurut Bourdieu merupakan hubungan sosial yang artinya suatu energi sosial hanya ada dan membuahkan hasilhasil dalam arena perjuangan dimana ia memproduksi dan diproduksi. Penukaran paling hebat yang telah dibuat adalah penukaran pada modal simbolik, sebab dalam bentuk inilah bentuk-bentuk modal yang berbeda dipersepsi dan dikenali sebagai sesuatu yang legitmit. Agar dapat dipandang sebagai seseorang atau kelas yang berstatus dan mempunyai prestise. Habitus berkaitan dengan modal sebab sebagian habitus berperan sebagai pengganda modal secara khusus modal simbolik. Modal dalam pengertian Bourdieu sangatlah luas karena mencakup: modal ekonomi, modal budaya, dan modal simbolik digunakan untuk merebut dan mempertahankan perbedaan dan dominasi

\section{PRAKTIK}

Teori praktik dikembangkan oleh Pierre Bourdieu, seorang ilmuwan sosial politik Perancis kelahiran Denguin, Pyrenia Atlantik, Perancis. Bourdieu menyatakan teori praktik sosial dengan persamaan: 
$($ Habitus x Modal $)+$ Ranah $=$ Praktik

Gambar 1. Persamaan teori praktik sosial Bourdieu

Rumus ini mengganti setiap relasi sederhana antara Individu dan struktur dengan relasi antara habitus dan ranah yang melibatkan modal (Maizier, 2009:xxi). Teori praktik merupakan gagasan pemikiran Bourdieu sebagai produk dari relasi habitus sebagai produk sejarah, dan ranah yang juga produk sejarah, yang mana dalam ranah ada pertaruhan, kekuatan-kekuatan serta orang yang banyak memiliki modal, serta orang yang tidak memiliki modal. Menurut Maizier (2009:xviii), habitus dan ranah merupakan perangkat konseptual utama seperti kekuasaan simbolik, strategi, dan perebutan (kekuasaan simbolik dan material), beserta beragam jenis modal (modal ekonomi, budaya dan simbolik).

\section{KEPEMIMPINAN}

Menurut Kadarman dan Udaya (1993:116), kepemimpinan didefinisikan sebagai seni atau proses untuk mempengaruhi dan mengarahkan orang lain agar mereka mau berusaha mencapai tujuan yang hendak dicapai oleh kelompok. Menurut Siagiani (2003:177-178), kepribadian merupakan suatu konsep yang dinamik yang berusaha menjelaskan pertumbuhan dan perkembangan keseluruhan sistem psikologis seseorang. Hal-hal seperti daya pikat, pandangan positif terhadap hidup, murah senyum, dan karakteristik lain seperti itu ternyata bukanlah yang dimaksud dengan kepribadian seseorang, meski pun karakteristik itu bersifat positif. Kepribadian seseorang dipengaruhi oleh paling sedikit tiga faktor, yaitu keturunan, lingkungan, dan situasi.

Karakteristik yang bersifat keturunan, yang dibawa sejak lahir adalah penampilan fisik, bentuk wajah, jenis kelamin, komposisi otot, tingkat stamina dan ritme biologis seseorang. Pada umunya karakteristik yang dibawa sejak lahir itu tidak dapat diubah. Berbagai karakteristik berikut hanyalah sebagian faktor yang membentuk kepribadian seseorang. Lingkunganpun turut berperan.
Menurut Rivai (2003:10-11), mengatakan ada beberapa teori yang mendukung dari diri seorang pemimpin, teori tersebut antara lain:

\section{- Teori Sifat}

Teori sifat merupakan teori yang menjelaskan sifat-sifat yang melekat dalam diri seorang pemimpin.

\section{- Teori Perilaku}

Di akhir tahun 1940-an para peneliti mulai mengeksplorasi pemikiran bahwa bagaimana perilaku seseorang dapat menentukan keefektifan kepemimpinan seseorang.

\section{- Teori Kepemimpinan Situasional}

Suatu pendekatan terhadap kepemimpinan yang menyatakan bahwa pemimpin memahami perilakunya, sifat-sifat bawahannya, dan situasi sebelum menggunakan gaya kepemimpinan tertentu.

Siagiani (2003:75) menyatakan bahwa situasi, kondisi, waktu dan tempat yang berbeda sangat mungkin menuntut penggunaan berbagai gaya kepemimpinan oleh seorang pemimpin. Salah satu keonsekuensi logis dari kenyataan demikian ialah bahwa ciri-ciri kepemimpinan digunakan atau ditonjolkan dengan bobot dan intensitas yang berbeda. Artinya berbagai ciri yang dimiliki oleh pimpinan yang pada dasarnya merupakan seorang pemimpin yang demokratik, dalam menghadapi situasi tertentu mungkin terpaksa menggunakan gaya yang otokratik.

Teori tentang analisis kepemimpinan berdasarkan ciri menurut Siagiani memberi petunjuk bahwa ciri-ciri ideal tersebut ada pengetahuan yang luas, kemampuan untuk bertumbuh dan berkembang, sifat inkuisitif, kemampuan analitik, daya ingat yang kuat, kapasitas integratif, keterampilan berkomunikasi secara efektif, keterampilan mendidik, rasionalitas, obyektivitas, pragmatisme, kemampuan menetukan skala prioritas, kemampuan membedakan yang urgen dan yang penting, rasa tepat waktu, rasa kohesi yang tinggi, naluri relevansi, keteladanan, kesediaan menjadi pendengar yang baik, adaptabilitas, fleksibilitas, ketegasan, keberanian, orientasi masa depan,sikap yang antisipatif dan proaktif 


\section{METODE PENELITIAN}

Jenis penelitian ini menggunakan jenis penelitian kualitatif. Menurut Moleong (2015:11), penelitian kualitatif adalah penelitian yang bermaksud untuk memahami fenomena tentang apa yang dipahami subjek penelitian misalnya perilaku, persepsi, motivasi, tindakan dan lain-lain. Metode pengumpulan data yang digunakan dalam penelitian ini yaitu metode pustaka. Pada proses pengumpulan data, peneliti menggunakan teknik simak dan catat. Di dalam menganalisis peneitian ini, peneliti menggunakan metode deskriptif.

\section{ANALISIS DAN PEMBAHASAN}

Dalam bab ini data yang telah terkumpul dianalisis berdasarkan habitus, arena, dan modal dari tokoh Oda Nobunaga. Lalu dilanjutkan membahas relasi ketiganya yang akan merujuk pada gaya kepemimpinan dari Oda Nobunaga. Pembagian ini ditujukan untuk mengulas realitas sosial tokoh Oda Nobunaga dapat dipahami secara utuh, khususnya pada gaya kepemimpinan Nobunaga.

\section{Habitus}

Oda Nobunaga adalah tokoh yang diceritakan menjadi seorang pewaris Oda Nobuhide. Diangkat menjadi pemimpin marga Oda sebagai pengganti ayahnya di usianya yang masih lima belas tahun, Nobunaga harus menjadi seorang pemimpin dari pengikutnya serta rakyat Owari, provinsinya. Di masa kepemimpinannya, Nobunaga dipandang remeh oleh orang-orang disekitarnya karena mereka menganggap Nobunaga adalah pewaris yang tidak bisa diharapkan. Orang-orang beranggapan rendah padanya karena di mata mereka Nobunaga tidak akan mampu menjadi seorang junjungan terhormat seperti Nobuhide, ayahnya. Pemikiran orang-orang tentang Nobunaga hanyalah seorang anak yang pandir, kasar dan bodoh. Sifat negatif itu semakin membekas di dalam pikiran mereka setelah terbukti melihat langsung perilaku tidak pantas yang ditunjukkan Nobunaga dalam upacara pemakaman Nobuhide.
信長のうつけ振り、粗粗暴、狂態は募 るばかりだある。それもおもうぼだっ た。

Nobunaga no utsuke furi, so sobō, kyōtai wa tsunoru bakaridaaru. Sore mo omō bodatta. Sifat pandir, kasar, dan tak tahu aturan yang terdapat dalam diri Nobunaga seakan-akan terus bertambah parah. Tetapi ia memang sengaja ingin memberikan kesan demikian pada orang $\underline{\text { lain. }}$

(D.2, J.1, H.337)

Namun pada penggalan kutipan berikut menjelaskan faktanya, apa yang diperlihatkan oleh Nobunaga itu bukanlah sifat alaminya, melainkan image yang sengaja di tampilkan demi mempertahankan kekuasaannya. Sifat pandirnya ini menjadi 'senjata' untuk mempertahankan posisinya, dan dapat mengelabui semua orang termasuk keluarga dan walinya sendiri.

Habitus yang ada dalam penggalan kutipan berikut dalam bentuk sebuah pola pikir. Pola pemikiran ini tumbuh sejak ia akan mengemban tanggung jawab menjadi seorang pemimpin marga Oda. Secara tidak langsung, sifat pandirnya sudah tertanam dan berkembang dalam dirinya seiring waktu berlalu.

\section{Arena}

Dalam novel Taiko, diceritakan wilayah hidup (arena) dari tokoh Oda Nobunaga. Arena Nobunaga tergolong dalam kelas dominan, kelompok orang bermodal yang membedakan kelasnya dari kelompok lain.

「落馬したら駒も捨てよ。木枝に絡ま れて旗差物を矢わば、旗差物も打ら捨 てて急げ。要るは、今川が本陣の核心 へ、真っ向に突き入って、治部大輔が 首見ることぞ。身軽がよし、空身が利 ぞ。———敵中にはいって敵を突き伏 すとも、いちいち首を揚げて手間取る まいぞ。斬り捨てに。突き捨てに。 ———次へ次へ今生の限り敵にまみえ よ。ゆめ、殊勲を人に見せんと思う な。見よがしの殊勲は、すでに殊勲に てはなきぞ。八幡照覧、信長の眼前、 ただきょうを一期と無我無性に㗢く者 ぞ真の織田武士なれ」 
'Rakuba shitara koma mo suteyo. Ki eda ni karama rete hatasashimono o ya waba, hatasashimono mo da ra sutete isoge. Iru wa, Imagawa ga honjin no kakushin e, makkō ni tsuki haitte, jibutaifu ga kubi miru koto zo. Migaru ga yoshi, karami ga ri zo.-—— Teki nakaniha itte teki o tsuki fusutomo, ichīchi kubi o agete temadorumai zo. Kiri sute ni. Tsuki sute ni.-—-Ji e tsugi e konjō no kagiri teki ni mamie yo. Yume, shukun o hito ni misen to omou na. Miyo ga shi no shukun wa, sudeni shukun nite Hanaki zo. Yahatashōran, Nobunaga no ganzen, tada kyō o ikki to muga mushōni hataraku mono zo shin no Oda Takeshi nare'

Nobunaga berseru pada pasukannya. "Jika kalian jatuh dari kuda, tinggalkan saja! Jika panji-panji tersangkut di dahandahan, biarkan saja! Pokoknya, bergegaslah! Yang penting adalah mencapai markas Yoshimoto dan mendapatkan kepalanya. Jangan bawa barang sama sekali! Terjanglah pasukan musuh dan tembus barisan mereka. Jangan buang waktu dengan memenggal setiap lawan yang berhasil kalian jatuhkan. Bantai mereka dan hadapi lawan berikut, selama tubuh kalian masih bernyawa. Kalian tak perlu berusaha menjadi pahlawan. Sepak terjang yang gagah berani tak bermanfaat sama sekali. Bertempurlah tanpa mementingkan diri sendiri, dan kalian akan menjadi pejuang Oda sejati."

$$
\text { (D.9, J.2, H.309) }
$$

Pada kutipan berikut menggambarkan arena kekuasaan Nobunaga dalam suatu situasi dimana dia dan prajuritnya akan menyerang markas Yoshimoto sebelum para pasukan Yoshimoto akan tiba ke benteng Kiyosu keesokan harinya. Pada arena pertempuran ini menjadikan kekuatan simbolis Nobunaga sebagai seorang pemimpin pasukan tampak. Modal sosial serta modal kekuasaan yang dimilikinya dapat mempertahankan status sosial yang dimilikinya didepan para bawahannya.

\section{Kapital}

Kapial atau modal yang dimiliki Nobunaga diantaranya ada modal sosial, budaya, dan simbolik. Salah satu data berikut menunjukkan modal yang dimiliki oleh Nobunaga

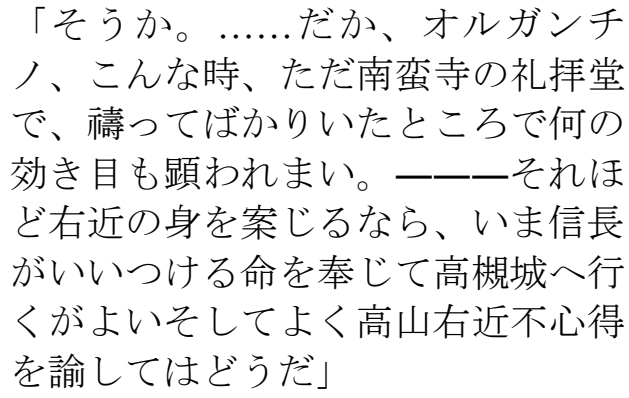

'Sō ka.......Da ka, oruganchino, kon'na toki, tada nanbanji no raihaidō de, Ino tte bakari ita tokoro de nani no kikime mo arawa waremai._- - Sorehodo ukon no mi o anjirunara, ima Nobunaga ga itsukeru inochi o hōjite Takatsuki shiro e ikuga yoi soshite yoku takayama ukon fukokoroe o satoshite wa dōda'

"Begitukah? Hmm, Padri Gnecchi, dalam keadaan seperti sekarang, doadoa yang dipanjatkan di gereja Tuan rupanya tidak membawa hasil. Kalau kecemasan Tuan mengenai Ukon memang begitu besar, Tuan tentu akan menaati perintah yang kuberikan sekarang. Kuminta Tuan mendatangi Benteng Takatsuki dan memberikan pencerahan pada Takayama Ukon mengenai perbuatannya yang tidak bijaksana."

(D.16, J.5, H.417)

Modal sosial dan budaya yang terdapat pada kutipan dialog tersebut adalah, Nobunaga yang meminta Padri Gnecchi untuk menasehati Takayama Ukon secara langsung. Karena Takayama Ukon pemeluk ajaran Nasrani, dan Nobunaga memilih untuk mengambil jalan lain selain peperangan. Nobunaga mengetahui bahwa dalih Takayama Ukon tidak begitu kuat untuk mendukung pemberontakan Arakhi Murashige. Sehingga Nobunaga berinisiatif untuk mengambil jalan tengah dengan jalan agama.

\section{Karakter kepemimpinan dalam relasi konsep Bourdieu.}

Pembahasan selanjutnya mengenai karakter kepemimpinan dari Nobunaga dengan 
teori praktik Bourdieu. Tidak hanya melalui teori praktik Bourdieu, melainkan didasari juga dari teori yang mendukung dari seorang pemimpin, yaitu teori sifat dan kepemimpinan situasional.

\section{Kepemimpinan berdasarkan situasional}

Karakter kepemimpinan Nobunaga yang terlihat ketika berada pada situasi yang berbedabeda, seperti ketika berhadapan dengan perilaku bawahannya, menentukan skala prioritasnya, keterampilannya dalam menganalisi suatu keadaan, dan dalam merencanakan masa depan untuk provinsinya.

\subsection{Fleksibelitas}

Sesuai dengan pengertian fleksibelitas dalam berjabat sebagai pemimpin, Nobunaga memperlihatkannya dalam berbagai situasi. Salah satunya ketika pengkhianatan yang terjadi dalam masa kepemimpinan Nobunaga..

\begin{tabular}{|c|}
\hline をも、謀叛人にいたしたは、皆、信 \\
\hline 長が不徳というものじや。一一信長 \\
\hline も以後はふかく反省しよう。そちた \\
\hline ちも，儂に仕えるものなれば、ふた \\
\hline 心など持つな。武門に生きる効もあ \\
\hline $\begin{array}{l}\text { るまい。一一武士は一道か、牢人か } \\
\text { ごゃ」佐渡は、眼が醒めた。 }\end{array}$ \\
\hline
\end{tabular}

"Iyaiya, Nakatsukasa o jigai sa se, sochi o mo, muhon'nin ni itashita wa, kai. Nobunaga ga futoku to iu mono ja.- Nobunaga mo igo wa fukaku hansei shiyou. Sochi-tachi mo, washi ni tsukaeru mono nareba, futa kokoro nado motsu na. Bumon ni ikiru kō moarumai._- Bushi wa ichi michi ka, rō hito ka ja' Sado wa, me ga sameta."

"Tidak, tidak. Akulah yang menyebabkan Nakatsukasa bunuh diri dan kalian berkhianat. Mulai sekarang, aku akan mempertimbangkan segala sesuatu dengan sungguh-sungguh. Dan kalian akan mengabdi padaku, dengan sepenuh hati. Kalau tidak, percuma saja menjadi pejuang. Mana yang lebih patut bagi seorang samurai, mengabdi pada junjungannya atau menjadi ronin tak bertuan?"

(D.18, J.1, H.409)
Situasi yang terjadi pada kutipan 18. Meski ia telah dikhianati oleh orang-orang kepercayaannya, Nobunaga tetap memaafkan mereka dan adanya menunjukan sirat penyesalan dengan apa yang telah diperbuatnya serta mengevaluasi dirinya untuk lebih baik kedepannya. Perbuatan Nobunaga ini diluar dugaan mereka, pandangan mereka yang biasa ditunjukkan Nobunaga didepan mereka seketika berubah, dan hal itu menyadarkan mereka betapa berbedanya sisi lain Nobunaga yang ia temui setelah mereka memohon ampun padanya. Dari hanya berlakon sebagai strategi untuk mempertahankan kekuasannya, sisi lainnya bercermin karena merasa insiden ini juga kesalahannya, merupakan bentuk habitus dalam sebuah pola pikirnya di ranah kekuasaannya sebagai junjungan.

\subsection{Kemampuan Menentukan Skala Prioritas}

Kondisi ekonomi di benteng Nobunaga tinggali mengharuskan Nobunaga memilih solusi yang tepat untuk langkah penghematan dalam kebutuhannya dan orang-orang yang tinggal disana.

\begin{tabular}{l} 
すると、その年の冬。 \\
今までの炭薪奉行、村井長門守は \\
免疫になって、その跡役へ、藤吉 \\
郎が奉行に任じられた。なせ、長 \\
門守が、役目を罷めさせられたの \\
か。 \\
そしてなぜ、自分が、炭薪奉行に \\
登用されたのか。藤吉郎は、信長 \\
から任命されると、命時に、それ \\
を考えてみた。「ははあ、炭薪の \\
費えを、もっと節約せよとの旨だ \\
な。いや、その旨は、一昨年から \\
\hline 出ているが、村井長門の節約ぶり \\
\hline では、お気に召さねのだな」で \\
\hline 一一彼は、広い城内の炭火のあ \\
\hline る所、薪を使用している所を、新 \\
奉行として、隈なく見て歩いた。
\end{tabular}

Suruto, sono-nen no fuyu. Ima made no sumimaki bugyō, Murai nagato nokami wa men'eki ni natte, sono ato-yaku e, Tōkichirō ga bugyō ni ninji rareta. Naze, nagato nokami ga, yakume o yame sase rareta no ka. Soshite naze, jibun ga, sumimaki bugyō ni tōyō sa reta no ka. Tōkichirō wa, Nobunaga 
kara ninmei sa reru to, inochi-ji ni, sore o kangaete mita. 'Wa hā, sumimaki no tsuie o, motto setsuyaku seyo to no muneda na. Iya, sonouma wa, ototoshi kara dete iruga, Murai Nagato no setsuyaku-buride wa, oki ni mesane noda na' de kare wa, hiroi Kiuchi no sumibi no aru tokoro, maki o shiyō shite iru tokoro o, shin bugyō to shite, kuma naku mite aruita.

Pada musim dingin itu, Murai Nagato, yang sampai saat itu bertugas sebagai pengawas arang dan kayu bakar, diberhentikan, dan Tokichiro ditunjuk sebagai penggantinya. Mengapa Nagato dipecat? Dan mengapa justru Tokichiro yang diangkat menjadi pengawas arang dan kayu bakar?Tokichiro merenungkan kedua pertanyaan itu pada saat menerima penugasan dari Nobunaga. Aha! Tuan Nobunaga ingin lebih menghemat arang dan kayu bakar. Ya, begitulah perintahnya tahun lalu, namun rupanya langkah penghematan yang diambil Murai Nagato tidak berkenan dihatinya.

$$
\text { (D.21, J.1, H.417) }
$$

Peraturan dalam tindakan mengusir yang dijalani Nobunaga berlaku pada seorang pekerja pengawas arang dan kayu bakar di bentengnya, Murai Nagato. Pada kutipan data berikut, menjelaskan pergantian posisi pekerjaan Tokichiro yang menjadi pengawas arang dan kayu bakar menggantikan Murai Nagato sebagai pengawas sebelumnya pun disadari melalui sebuah alasan yaitu penghematan. Modal (budaya) yang dimiliki oleh Nobunaga sebagai pemimpin, menjadi faktor pengaruh Nobunaga dalam menunjukkan habitusnya. Kasus lainnya pun pada saat Tokichiro naik pangkat menjadi pengawas pembangunan benteng, karena dinilai usul Tokichiro dalam pembangunan benteng tersebut lebih meyakinkan untuk selesai lebih cepat dari yang diperkirakan Nobunaga. Sehingga, Nobunaga lebih memprioritaskan usul Tokichiro yang menurutnya lebih baik untuk kebaikan wilayahnya.

\subsection{Kemampuan Analitik}

Dunia pertempuran, adu tombak, lempar panah bukan hal asing bagi Nobunaga. Begitupun dengan penyusunan taktik atau strategi tentang wilayah pertempuran.

\begin{abstract}
信長はもとより、前衛部隊のいるよう な地点にはなかった。太子ケ嶽を縦横 して、いきなり田楽挟間の直前へけあ らわれ、鬨の声をあげた時は、もう信 長自身でさえ、槍をふるって、義元の 幕下の士と、戦っていた。信長に槍を つけられた敵の士は、それが信長とは 恐らく知らなかったろう。敵の二、三 名を突き伏せて、信長はなおも、本陣 の幕へ近く馸け奇っていた。

Nobunaga wa motoyori, zen'ei butai no iru yōna chiten ni wa denakatta. Taishi ke Take tateyoko shite, ikinari dengaku Hasama no chokuzen e kake araware, to kinoko e o ageta toki wa, mō Nobunaga jishinde sae, yari o furutte, Yoshimoto no makushita no shi to,-sen tte ita. Nobunaga ni yari o tsuke rareta teki no shi wa, sore ga Nobunaga to wa osoraku shiranakattarou. Teki no ni, san-mei o tsuki fusete, Nobunaga wa naomo, honjin no maku e chikaku kake ki tte ita.
\end{abstract}

Sejak semula Nobunaga sengaja menghindari perkemahan barisan depan. Ketika mereka melewati Taishigadake dan menuju Dengakuhazama. Nobunaga sendiri ikut mengacungkan tombak dan melawan prajurit-prajurit Yoshimoto. Kemungkinan besar para prajurit yang menjadi korban tombak Nobunaga tidak mengetahui siapa lawan mereka. Setelah mencederai dua atau tiga orang. Nobunaga berderap ke arah petak berurai.

(D.23, J.2, H.317)

Modal intelektual yang dimilkinya menjadikannya habitusnya dalam arena pertempuran menjadi terwuujud sesuai yang diinginkannya. Kemenangan dalam setiap perlawanan sudah menjadi salah satu tujuan Nobunaga sebagai seorang pemimpin marga Oda, hal itu merupakan bentuk habitus darinya.

\subsection{Orientasi Masa Depan}

Pandangan Nobunaga tentang masa depan yang diinginkannya semakin memotivasinya untuk mewujudkan impiannya. Bukan hanya dalam pandangan kemenangan di setiap 
pertempuran namun dalam membangun masa baru dengan budaya baru yang lebih maju.

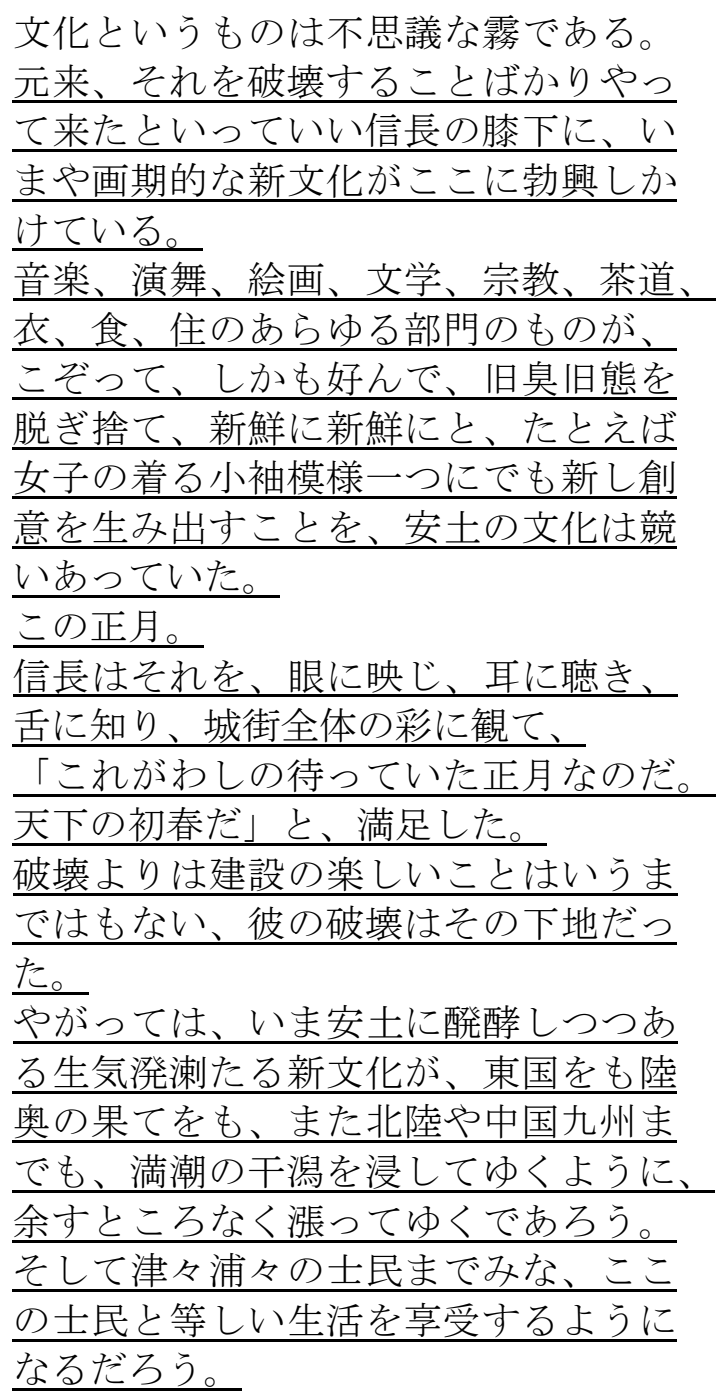

Bunka to iu mono wa fushigina kiridearu. Ganrai, sore o hakai suru koto bakari yattekita to itte i Nobunaga no hizamoto ni, imaya kakkitekina shin bunka ga koko ni bokkō shikakete iru. Ongaku, enbu, kaiga, bungaku, shūkyō, sadō, i,-shoku, jū no arayuru bumon no mono ga, kozotte, shikamo kononde, furukusa kyūtai o nugisute, shinsen ni shinsen ni to, tatoeba joshi no kiru kosode moyō hitotsu ni demo atarashi sōi o umidasu koto o, Azuchi no bunka wa kisoi atte ita. Kono shōgatsu.

Nobunaga wa sore o, me ni eiji, mimi ni kiki, shita ni shiri,-jō-gai zentai no aya ni mite, ‘kore ga washi no matteita shōgatsuna noda. Tenka no hatsuharuda' to, manzoku shita. Hakai yori wa kensetsu no tanoshī koto wa iu made wa mo nai, kare no hakai wa sono shitajidatta. Ya gatte wa, ima Adzuchi ni hakkō shitsutsu aru seikihatsuratsutaru shin bunka ga, tōgoku o mo michinoku no hate o mo, mata Hokuriku ya Chūgoku Kyūshū made mo, manchō no higata o hitashite yuku yō ni, amasu tokoro naku minagitte yukudearou. Soshite tsutsuuraura no shimin made mina, koko no shimin to hitoshī seikatsu o kyōju suru yō ni narudarou.

Apa yang kita sebut "budaya" sesungguhnya menyerupai kabutkedua-duanya tak dapat diraba. Yang bermula sebagai tindakan penghancuran kini tiba-tiba membentuk sebuah budaya baru, tepat di depan kaki Nobunaga. Dalam seni musik, seni teater, seni lukis, kesusastraan, seni minum teh, pakaian, seni memasak, serta arsitektur, sikap dan gaya lama dicampakkan, digantikan oleh yang baru dan segar. Pola-pola baru untuk kimono wanita pun saling berlomba dalam budaya Azuchi yang berkembang pesat ini.

Inilah Tahun Baru yang kutunggu-tunggu. Tahun Baru bagi bangsa ini. Rasanya tak perlu dijelaskan bahwa membangun lebih menyenangkan dari-pada menghancurkan, pikir Nobunaga. Ia membayangkan bahwa budaya baru yang penuh dinamika itu akan datang bagaikan air pasang, membanjiri provinsi-provinsi timur, bahkan daerah barat dan Pulau Kyushu, tanpa menyisakan sejengkal tanah pun.

$$
\text { (D.24, J.5, H.425-426) }
$$

Bentuk mindset yang dihasilkan dari rencananya untuk membuat masa orde baru yang diimpikannya adalah bentuk habitus dari Nobunaga dalam arena kekuasaan untuk memajukan kesenian-kesenian baru yang didapat dari negara barat maupun timur. Keterlibatan modal budaya dan sosial yang dimiliki Nobunaga sebagai pemimpin marga dan wilayah yang memiliki akses dengan orangorang dari negara barat dan timur.

\section{Kemampuan Berdasarkan sifat}

Nobunaga menunjukkan sifat-sifat yang mencerminkan dirinya sebagai seorang pemimpin dalam bertindak maupun dalam mengambil keputusannya

\subsection{Ketegasan}


Sebagai seorang penguasa marga Oda, Nobunaga memfokuskan seluruh atensinya pada wilayah provinsi dan pemerintahan yang terjadi semasa ia memegang jabatan itu. Contoh ketegasan pada Nobunaga terdapat dalam kutipan berikut.

清盛のは私の怒気だ。彼一門の擁護に すぎぬ。一一信長はちがう。そんな 㑩い痴人の夢を、この地上に描くため 、夥しい血と兵綮を弄ぶものではない 。一——信長は信長のために戦はせぬ 。わしの戦は、わしをして旧弊のあら ゆる邪魔ものを破壊させ、また、わし をして生々たる新しい世を打建てよと 命じる———神か、民か、時か——— 何か知らぬが、うけたる使命によって 戦うのみだ。そちたちは気が小さい、 眼がせまい。そちたちの嘆きは、小人 のかなしみだ。そち達の説く利害は、 信長一個を出ておらぬ。㕡出のごとき を、灰としようが、無辺の国土と、か きりない衆民を擁してゆく生々の末ま でを思えば、何ほどのことがあろう」

Kiyomori no wa watashi no dokida. Kare ichimon no yōgo ni suginu.——— Nobunaga wa chigau. Son'na hakanai chijin no yume o, kono chijō ni kaku tame, obitadashì chi to heisen o moteasobu monode wanai._-_Nobunaga wa Nobunaga no tame ni tatakaha senu. Washi no sen wa, washi o shite kyūhei no arayuru jama mono o hakai sa se, mata, washi o shite seiseitaru atarashì yo o da tateyo to meijiru - - -shin ka,-min ka,-ji ka-_nanika shiranu ga, uketaru shimei ni yotte tatakau nomida. Sochi-tachi wa kigachisai, me ga semai. Sochi-tachi no nageki wa, kobito no kanashimida. Sochi-tachi no toku rigai wa, Nobunaga ikko o dete oranu. Akira-de nogotoki $o$, hai to shiyō ga, muhen no kokudo to, ka kirinai shūmin o yōshite yuku seisei no sue made o omoeba, nani hodo no koto ga arou'

"Aku berbeda. Aku tidak bertempur demi kepentingan sendiri. Dalam pertempuran ini, peranku adalah menghancurkan kebusukan lama dan membentuk dunia baru. Aku tidak tahu apakah ini keinginan para dewa, keinginan rakyat, atau panggilan zaman. Aku hanya tahu bahwa aku akan menjalankan perintah yang kuterima. Kalian semua takut, dan pandangan kalian terbatas. Seruan kalian adalah seruan orang berpandangan picik. Keuntungan dan kerugian yang kalian bicarakan hanya menyangkut aku sebagai individu. Kalau aku bisa melindungi provinsi-provinsi dan menyelamatkan nyawa yang tak terhitung jumlahnya dengan mengubah Gunung Hiei menjadi neraka, aku telah mencapai keberhasilan besar."

(D.26, J.4 H.189)

Dalam konteks kutipan berikut, Nobunaga memberikan penegasan tentang rencana pertempuran yang dilakukannya kepada para prajuritnya. Hal yang mendasari Nobunaga bersikap tegas ialah karena para prajuritnya yang ikut pada pertempuran itu mencoba menghalangi niat Nobunaga untuk menyerang serta menghancurkan gunung Hiei. Modal budaya serta sosial yang dimiliki Nobunaga dapat memperlihatkan simbol kekuasaan Nobunaga pada posisi status sosialnya yang tinggi.

\subsection{Keteladanan}

Sebelum Nobunaga naik tahta menjadi pemimpin, tentunya pemimpin sebelumnya memiliki sebuah peraturan yang mana akan diturunkan pada pewaris selanjutnya dalam bentuk konkret maupun abstrak. Nobunaga sebagai pewaris tersebut akan mengetahuinya dan harus menuruti peraturan lama itu menjadi sebuah kewajiban. Berikut merupakan bentuk keteladanan yang dilakukan oleh Nobunaga.

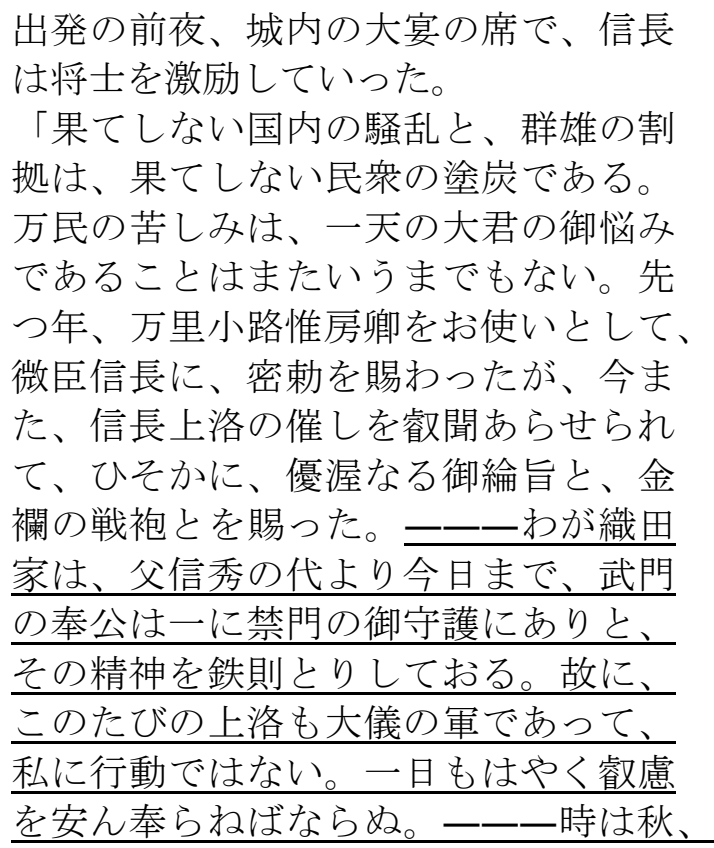


汝らの飼馬も肥えておらう。各〜、信 長旨を旨として、おくるるな、違うな、 あだに死ぬな。粉骨砕身、大君のいま す都まで押し進めよ」

Shuppatsu no zen'ya, Kiuchi no dai utage no seki de, Nobunaga wa shōshi o gekirei shite itta. 'Hateshinai kokunai no sōran to, gun'yū no kakkyo wa, hateshinai minshū no totandearu. Banmin no kurushimi wa, itten no taikun no o nayamidearu koto wa mata iu made mo nai. Sakitsu-nen, madenokōjinobufusakyō o otsukai to shite, bi shin Nobunaga ni, micchoku o tamawattaga, ima mata, Nobunaga jōraku no moyōshi o eibun arase rarete, hisoka ni, yūakunaru gorinji to, kinran no senpō to o tamawatta. Waga Oda-ka wa, chichi Nobuhide no dai yori kyō made, bumon no hōkō wa ichi ni kinmon no o shugo ni ari to, sono seishin o tessoku tori shite oru. Yueni, kono tabi no jōraku mo taigi no gundeatte, watashi ni kōdōde wanai. Ichinichi mohayaku eiryo o yasu n matsuraneba naranu.-_-_i wa aki, nanji-ra no kaiba mo koete orou. Kaku , Nobunaga mune o mune to shite, okururuna, chigauna, adani shinuna. Funkotsusaishin, taikun no imasu miyako made oshisusumeyo'

Nobunaga berkata kepada para perwira dan anak buahnya. "Kekacauan di negeri ini, yang merupakan akibat dari persaingan para panglima provinsi, menyebabkan penderitaan berkepanjangan bagi rakyat. Tak perlu disebutkan bahwa kesengsaraan yang melanda seluruh negeri menimbulkan kesedihan bagi sang Tenno. Sejak zaman Ayahanda, Nobuhide, sampai sekarang. marga Oda berpegang pada peraturan tak tertulis bahwa kewajiban utama seorang samurai adalah melindungi sang Tenno beserta kerabatnya. Jadi, pada waktu menuju ibu kota, kalian tidak bertempur untukku, melainkan atas nama sang Kaisar."

$$
\text { (D.28, J.3, H.331-332) }
$$

Keteladanan Nobunaga ini dapat disebut habitus, karena ajaran tentang kewajiban sebagai seorang samurai telah tertanam dalam diri Nobunaga. Meskipun peraturan yang ada sejak zaman kepemimpinan Nobuhide tidak dalam berbentuk konkret, tetapi marga Oda tetap memegang kesetiaan untuk bertempur melindungi sang Tenno (Kaisar).

\section{PENUTUP}

Berdasarkan hasil penelitian, dapat disimpulkan bahwa tokoh Oda Nobunaga dalam novel Shinsho Taikouki ditemukan habitus, arena, dan modal serta kombinasi ketiganya yang menggambarkan bentuk karakter kepemimpinan tokoh tersebut.

Bentuk habitus dari tokoh cerita mengalami pergerakan dari waktu ke waktu akibat dari pembelajaran dalam menentukan tindakan. Pertumbuhan ini diakibatkan oleh pengalaman, didikan serta keadaan lingkungannya. Pengaruh habitus Oda Nobunaga timbul yaitu faktor kelas dominan yang dimilikinya. Faktor itu mendukungnya untuk mempertahankan posisi kelas sosialnya untuk tetap berada diatas.

Terdapat tiga arena ditemukan dalam tokoh Oda Nobunaga. Pertama, arena kekuasaan. arena perekonomian dan arena Intelektual. Modal pada Nobunaga terdiri dari tiga modal yaitu ada modal simbolik, modal budaya dan modal sosial. Ketiga modal tersebut dapat menonjol dari pengaruh arena dan habitus dari Nobunaga.

Karakteristik kepemimpinan dari relasi ketiga konsep Bourdieu pada Oda Nobunaga: Fleksibelitas, Kemampuan menentukan skala prioritas, Kemampuan analitik, Orientasi masa depan, Berpendirian teguh, Ketegasan, Keteladanan.

\section{DAFTAR PUSTAKA}

Bourdieu, Pierre. 2012. Arena Produksi Kultural: Sebuah Kajian Sosiologi Budaya. (Yudi Santosa Pentj.). Yogyakarta: Kreasi Wacana.

Esten, Mural. 2013. Kesusastraan Pengantar Teori dan Sejarah. Bandung: CV Angkasa

Faruk. 2016. Pengantar Sosiologi Sastra. Yogyakarta: Pustaka Pelajar

Fahdiah, Syarifaeni. 2019. Sastra dan Budaya Lokal: (Konstruksi Identitas Masyarakat Banten Dalam Seni Pertunjukan Debus). Ponorogo: Uwais Inspirasi Indonesia

Harker, Richard, dkk. (ed.). 2009. (Habitus x Modal $)+$ Ranah $=$ Praktik $:$ Pengantar 
Paling Komperhensif Kepada Pemikiran Pierre Bourdieu. (Pipit Maizier Pentj.). Yogyakarta: Jalasutra

Kadarman, A. M, dan Jusuf Udaya. 1993. Pengantar Ilmu Manajemen. Jakarta: PT Gramedia Pustaka

Moleong, Lexy. J. 2015. Metodologi Penelitian Kualitatif. Bandung: PT Remaja Rosdakarya.

Rivai, Veithzal. 2003. Kepemimpinan dan Perilaku Organisasi. Jakarta: PT Grafindo Persada.

Ritzer, George dan Douglas J. Goodman. 2008. Teori Sosiologi. (Nurhadi Pentj.). Yogyakarta: Kreasi Wacana

Siagiani, Sandang P. 2003. Teori dan Praktek Kepemimpinan. Jakarta: PT Rineka Cipta
Yoshikawa，Eiji. 1990. 新書 太閤 記 (ShinshoTaikouki). Tokyo: Kodansha.

2006. Taiko: Novel Epik tentang Perang dan Kemenangan pada Zaman Feodal di Jepang (Penerjemah: Hendarto Setiadi). Jakarta: Gramedia Pustaka Utama.

Wattimena, Reza A.A. 2012. Berpikir Kritis bersama Pierre Bourdieu.

http://rumahfilsafat.com/2012/04/14/sosiolo gi-kritis-dansosiologireflektif-pemikiranpierrebourdieu/

Akses September 2019.

Kuswandoro, Wawan, 2016. Pemikiran Pierre Bourdieu dalam Memahami Realitas Sosial. http://wkwk.lecture.ub.ac.id/2016/01/pemikir an-pierre-bourdieu-dalam-memahami-realitassosial/

Akses Januari 2020 